DOI https://doi.org/10.30525/978-9934-571-83-1-8

\title{
SUPPLEMENTARY PATENT PROTECTION AND DATA EXCLUSIVITY IN THE PUBLIC HEALTH SCOPE: LEGISLATION OF UKRAINE AND THE EU CONTEXT
}

\author{
Klochko T. Yu.
}

\section{INTRODUCTION}

The unconventional nature of medical products as objects of civil rightsis undiscussable, as they combine therapeutic functions and with this they serve as source of profit for manufacturing companies. Such diversification of purpose of a medical products requires the creation of reliable tools and mechanisms for achieving a balance between interests of society and the market. One of such instruments is patenting as a system of tools that allows any person to be granted with exclusive rights on taken decision upon the ways and the modes on the invention implementation. However, the point on medical drugs creation seems to be enough sensitive as it relates not only to the balance between interests of inventors (interest to get the reinvestment from the patented product realization) and patients (interest to get access to medical product to ensure the right for the health care) but also relates to coexistence of such interests in different pieces of legislations.

Research activities over innovative medical products is the longue process even despite the fact that modern scientists have the full access to all resources dedicated to new innovative researches and studies, which allow to identify the maximum number of the scientific sources relevant to the problem research for the short period. However, the way of the new medical product creation takes more than 10 years in average, the rate of the chemical substances screening is enough high and very limited number of invented chemical substances have the potential to be used in the new medical drug; moreover in average the reinvestments done for the creation of the innovation are possible only in 18 years after the registration of product as the invention by the state institutions on intellectual property rights protection ${ }^{1}$.

Therefore, the patenting is one of the strong tools which motivates innovative researches for the new trials and pharmaceutical industries to invest to such researches. At the same time such high role of the health care products patenting requires the flexibilities in the existed legislation in terms of the fixation of the balance between the inventors and patients interests. Mostly such flexibilities

\footnotetext{
${ }^{1}$ Кириченко І.А. Деякі аспекти патентного захисту лікарських засобів. Інтелектуальна власність. 2001. № 9-10. С. 17-24.
} 
are centered around the legislation on terms for exclusive patent rights protection and on terms during which the information on the clinical and preclinical trials could not be discovered for generic medicines production. Therefore, the research on terms for the invention protection, including requirements to supplementary protection, as well as requirements on information on clinical and pre-clinical trials protection requires additional study. In the current research, we will focus on two tools, which somehow create the obstacles to get access for the generic medicines by patients and creates the benefits for the medical products manufacturers, namely supplementary patenting protection and data exclusivity information protection. By the end of the research, we would like to show the difference in the approaches defined in the Ukrainian legislation and the legislation of the EU to supplementary patent protection as well as particularities in regulation of the clinical and pre-clinical studies and data protection.

\section{Supplementary patent protection under legislation of the EU and Ukraine}

Modern traditions of determining the time limits of patent protection are set in Art. 33 of the TRIPS Agreement on April 15, 1994, according to which the term for the patent protection validity should not expire earlier than 20-year period from the date of the application filing ${ }^{2}$. At the same time, it should be noted that the inventors have not been always endowed with the certain period for the realization of their own rights to inventions, since inventors were not always the subject for the intellectual rights protection. O.A. Podoprigora noted thatthe exclusive right to an invention protected by the copyright certificate belonged to the State; in its turn, the exclusive rights of the State to the invention was not limited due to such approach in regulation ${ }^{3}$.

The first attempt to resolve issues related to the protection of patents was the Council of People's Commissars Resolution dated on June 30, 1919 and named "The Regulations on Inventions". In fact, mentioned document became the first regulatory document which established approaches to inventors rights protection in the USSR ${ }^{4}$. And already in September 12, 1924, the Central Executive Committee and the Council of People's Commissars of the USSR adopted a new document - the Decree "On Patents and Inventions", which, as E.F. Melnyk noted, became the document where specific rights of the inventors were

\footnotetext{
2 Угода про торговельні аспекти прав інтелектуальної власності від 15 квітня 1994 p. URL: http://zakon4.rada.gov.ua/laws/show/981_018.

${ }^{3}$ Підопригора О.А. Нове законодавство про винахідництво і раціоналізацію : методична розробка ; КДУ ім. Т.Г. Шевченка. Київ, 1975. С. 61.

4 Вишневецкий Л.М., Иванов Б.И., Левин Л.Г. Формула приоритета: возникновение и развитие авторского и патентного права. Ленинград : Наука. Ленигр. отд-ние, 1990. С. 165.
} 
specified. In particular it included the provision that the inventors rights should be protected by certificate during 15 years starting with the date of the official publication of the information on invention registration. Moreover, the document allowed such period extention to additional 5 years. At the same historical period the legislative provisions in modern EU countries had some differences. Thus the maximum patentprotection period in France was 20 years; at the same time, it was possible to apply for the certificate on patent protection with validity for 5,10 or 15 years, but in such a case, the extension was not allowed $^{5}$. In the United States, the validity of the patent was 17 years strating with the date when protection certificate was issued and cases of prolongation of the patent validity were rare ${ }^{6}$.

The possibility for the patent certificate validity extention is reflected in the modern Ukrainian legislation. Thus according to clause 4 of Art. 6 of the Law of Ukraine "On Protection of Rights to Inventions and Utility Models" the priority, authorship and title to the invention shall be certified by a patent or a declarative patent and the term of their validity should be 20 and 6 years accordingly. And the validity of the patent to the medical product which is the object of the invention and use of which requires approval of the state institution, might be extended at the request of the holder of this patent for a period equal to the period between the date of filing of the application and the date of the receipt of such permission, but not more than 5 years. Thus, the legislator gives the producers of the medical product who take all forces for its creation and placement to the market the possibility to the extension of their intellectual property rights.

In the context of the point related to prolongation of the patent validity in the sphere of medicines production, special attention should be paid to the declarative patents that were introduced as a temporary document and which certifies the rights of patent holders, and might be provided through the results of formal examination.

Thus, by the decision of the Verkhovna Rada of Ukraine on December 23, 1993 it was determined that before the creation of the necessary patent information base, Ukraine's patents for inventionsmight be issued without examination of substantive applications up to 5 years starting with the date of filing an application under the responsibility of its owner without patent validity warranty $^{7}$. According to A. Krasovskaya and L. Glukhivsky, the main

\footnotetext{
Свядосц Ю.И. Основные положения патентного права Франции / под общ. ред. М.М. Богуславского ; Гос. ком. по делам изобретений и открытий СССР. Центр. науч.-исслед. ин-т патентной информации и техн.-экон. исследований. Москва, 1965. С. 21-22.

${ }^{6}$ Гарилов Э.П. Основные положення патентного права США / под общ. ред. М.М. Богуславского. Москва : ЦНИИПИ, 1966. С. 48-49.

${ }^{7}$ Про введення в дію Закону України «Про охорону прав на винаходи і корисні моделі» : Постанова Верховної Ради України від 23 грудня 1993 р. № 3769-XII. URL: http://zakon2.rada.gov.ua/laws/show/3769-12.
} 
prerequisites for the introduction of declarative or short-term patents in Ukraine was the short procedure for their issuing (up to 6 months), while the applicant had to wait at least two years for the issue of a 20 -year patent. At the same time, scientists also note the "weakness" of the declarative patent, since any third party while assessing the patentability of an invention protected by a declarative patent is able to rely only on the application (declaration), and, accordingly, on the document issued for the decision, which is in fact not patentable ${ }^{8}$. In its turn, the adjective "declarative" had to emphasize that the applicant requesting the patent, declares on his behalf that the invention claimed by him is patentable. In this case, the Statedoes not carry out an expert examination of this invention and does not give any guarantees ${ }^{9}$.

The Instruction on the procedure for extending the period of the patent validity for the invention, the object of which is product, the use of which requires the approval of the competent authority, is approved by the order of the Ministry of Education and Science of Ukraine on May 13, 2002 № 298, is in force in Ukraine since $2002^{10}$. According to Clause 1.2 , the term of validity of the patent for an invention the object of which is a product and the use of which requires the permission of the relevant competent authority may be extended for a period equal to the period between the date of filing an application for an invention and the date of receipt of such permission, but not more than for 5 years (the specified norm is identical to the norm of Article 6 of the Law of Ukraine "On Protection of Rights to Inventions and Utility Models").

In the analysis of the above mentioned provision, there is a question regarding the harmonization of the concepts of extending the validity of the patent and the maximum 20 years term of inventions protection in accordance with the TRIPS Agreement.

In this regard, we propose to refer to the legislation of the European Union where additional patent protection has been existed since 1992. For example, in the European Union, the issue of additional patent protection is regulated in the context of the system oncertificates of supplementary protection described in the Regulation № 469/2009 of the European Parliament and of the Council of Europe on May 9, 2009 "On Supplementary Medicinal Products Certificates (Codified Version)" (herein after - Regulation № 469/2009) ${ }^{11}$.

\footnotetext{
${ }^{8}$ Красовська А., Глухівський Л. Деклараційний патент на винахід : завершення життєвого циклу і підсумки. Інтелектуальна власність. 2004. № 3. С. 35-36.

${ }^{9}$ Глухівський Л. Деклараційний патент : за і проти. Інтелектуальна власність. 2001. № 7. С. 9-11.

10 Інструкція про порядок продовження строку дії патенту на винахід, об'єктом якого є засіб, використання якого потребує дозволу компетентного органу : затв. наказом Міністерства освіти і науки України від 13 травня 2002 р. № 298. URL: http://zakon3.rada.gov.ua/laws/show/z0453-02.

${ }^{11}$ Supplementary protection certificate for medicinal products : Regulation of the European Parliament and of the Council on 6 May 2009 № 469/2009. Official Journal. 2009. P. 1-10. URL:
} 
The purpose of the adoption of Regulation № 469/2009, which was preceded by the Council Regulation № 1768/92 on June 18, 1992, "On the creation of a certificate of supplementary protection of medicinal products", is reflected in the several points set out in the preamble. Thus, it states that pharmaceutical researches play a significant role in improving the health of the population, and the creation of favorable conditions for adequate protection should encourage the development of medical products, especially those resulting from long-term and costly research. At the same time, the period that arises between filing an application for a patent for a new medicinal product and obtaining a marketing authorization for such a product is considered inadequate for effective patent protection, which may adversely affect pharmaceutical research. Also the Article 4 of the Regulation № 469/2009 states that protection conferred by a certificate shall extend only to the product covered by the authorisation for market placement.

Distinction of the objects which should be under protection is identified as problematic in common law of the EU Court of Justice.

Thus, under the circumstances of the case № C 322/10 which was considered by the European Court of Justice on April 26, 1990, Medve Company filed an application for a European patent for a method for manufacturing an anticonvulsant cough non-cellular vaccine, which included a combination of two antigens as active ingredients called"pertactin" and "thread-like hemagglutinin" in such a composition to ensure the efficiency of the vaccine. In this regard, the company filed four applications for additional protection certificates for the vaccine against three more diseases, except convulsive cough. In addition, the company added the obtained permissions for the placing of medicinal products on the market, which included additional ingredients in addition to pertacetine and filamentous hemagglutinin. The European Union Patent Office rejected the application for additional protection certificates on the grounds that it did not meet the requirements of Regulation № 469/2009, because the medicinal product for which the application for the certificate of supplementary protection was filed, included 9 active ingredients, that is, more than had been claimed in the main Patent. Here, Court arrived to the conclusion that the provisions of Regulation № 469/2009 should be understood as a warning to the competent authorities to issue additional protection certificates for those active ingredients that are not protected by the main patent. Moreover, supplementary protection certificates protect the same rights as the main patent and, accordingly, can not be issued for those ingredients that are not protected by the main patent, even if such ingredients are included in the medicinal product authorized for placement on the market. At the same time, and this is important, inclusion in the product

http://eurlex.europa.eu/Notice.do?val=496552:cs\&lang=en\&list=496852:cs,496552: $\mathrm{cs}, \&$ pos=\&page $=1 \& \mathrm{nbl}=2 \&$ pgs $=10 \&$ hwords $=\&$ checktexte $=$ checkbox \&visu=\#texte. 
of other substances that are not protected by a patent is not a ground for refusal to issue a certificate of supplementary protection, but its effect will extend exclusively to those components that have alreadyreceived protection ${ }^{12}$.

The EU Court case № C 422/10 is similar to the one described ${ }^{13}$. In June 24, 1993 Georgetown University applied for a European patent on the vaccine "papilloma virus", which was issued December 12, 2007 (23 June 2013 was defined as the term for patent expiration). Simultaneously permission for placement was issued for the medicinal product which contained the active ingredients that are out of scope for the protection by the basic patent, and thus the Patent Office rejected the application for a supplementary protection certificate. In this case, the same judgment was based on the position that a supplementary protection certificate shall be issued only to those active ingredients which are protected by the basic patent regardless of whether it belongs to the medical product which received approval for the placing on the market, other active ingredients, unprotected with the main patent.

In another case № C-518/10 and the corresponding decision of the EU Court ${ }^{14}$ the Yad Ressorch Company is the holder of the patent for a composition of substances consisting of two active ingredients. On November 2, 2004 the applicant applied for an additional protection certificate for only one active ingredient included in the composition. At the same time, the permission to place a medicinal product on the market also contained information on only one active ingredient. Despite this, in its decision the EU Court stated that the supplementary protection certificate can not be issued on a separate ingredient that has received patent protection but only in combination with another ingredient.

These cases clearly demonstrate the fact that certificates on supplementary protection can protect the rights of owners only to those products and their components that have been protected by the main patent.

In the Court case № C-442/11 ${ }^{15}$ the United Kingdom National Patent Office issued patent for Valsartan as an active ingredient used in the treatment of high pressure and also recommended for use in heart failure and post-infarction. On the basis of this patent the permission to place it on the market was granted to

\footnotetext{
12 Judgment of the Court on 24 November 2011 № C-322/10. URL: http://eur-lex.europa.eu/legalcontent/ EN/TXT/?uri=OJ\%3AC\%3A2012\%3A025\% 3AFULL.

${ }^{13}$ Judgment of the Court on 24 November 2011 № C-422/10. URL: http://curia.europa.eu/juris/document/ document.jsf?docid $=115204 \&$ doclang=en.

${ }^{14}$ Order of the Court (Fourth Chamber) of 25 November 2011 № C518/10. URL: http://eur-lex.europa.eu/ legalcontent/EN/TXT/?qid=1480780405738\&uri=CELEX:62010CB0518.

${ }^{15}$ Order of the Court on 9 February 2012 № Case C-442/11. URL: http://curia.europa.eu/juris/document/ document.jsf?text $=\&$ docid $=120021 \&$ pageI

ndex $=0 \&$ doclang $=E N \&$ mode $=1$ st $\&$ dir $=\& o c c=$ first $\&$ part $=1 \& \operatorname{cid}=33888$.
} 
company Novartis, which included a specified component for which a certificate on supplementary protection was received.

Subsequently, Novartis developed a new drug called Ko-Diyavan, which, in addition to the "Valsartan" component, included others that enhanced the healing effect of heart disease and post-infarction. However, the developers did not apply to the National Patent Office for obtaining a supplementary protection certificate for Valsartan in combination with hydrochlorothiazide. After the patent protection has been terminated, another pharmaceutical company had released a generic version of the medicinal product, which included the specified components. In this regard, Novartis appealed to the Court against Actavis, stating that the placement of the medicinal product "Actavis" violates the rights protected by the supplementary protection certificate issued for the Valsartan component. However, the Actavis company has emphasized that the supplementary protection certificate protects only the Valsartan component, despite the fact that the permit for market placement received for the medical product, which, in addition to this component, included hydrochlorothiazide. In this regard, the Court of Justice of the European Union decided that the supplementary protection certificate protects the "product" consisting of an active ingredient that received patent protection, and the patent holder could rely on the protection granted by the main patent for such "product" in the part of the prohibition market placement of medicinal product comprising an active ingredient in combination with one or more active ingredients. But the certificate on supplementary protection on the "product", after the termination of the main patent, does not entitle its holder to prohibit a third person from placing a medicinal product with the same composition as the "product" in respect of which patent protection is no longer valid, when the permit for placing on the market was issued before the certificate expired.

The analysis of the mentioned above cases shows that the certificates of supplementrary protection are more dualistic because, on the one hand, they grant the same person with the same rights as the main patent, on the other hand, they are not bound to the validity of the patent and are dependent on the granting of the permit for medical product market placement.

In addition, Yu.M. Kapitsa points out that the legislator in the European Union has decided a dilemma, according to which, on the one hand, it was necessary to create conditions for the promotion of research activities in the pharmaceutical industry by introducing a higher level of protection of intellectual property, which is the result of such activity, but on the other hand not to create provisions contradicting the current international legal regime of protection of inventions. In addition, the researcher points out that the differences in the "binding" to the provisions of supplementary protection in 
national legislation and legislation of the European Union do not indicate a lack of legal regulation in Ukraine, but are explained solely by the particularities of the international legal regulation applicable in all European Union Member States ${ }^{16}$.

In this regards it's also very important to point out one addition particularity of the EU and Ukraine regulations in the field of the supplementary certificates issue which is reflected in the court cases.

The Kyiv Economic Court of Appeal, in its judgment in case № 910/21281/14 of February 10, 2015, reviewed the appeal by Dr. Reddy's Laboratoris Limited (Limited Liability Company) regarding invalidation of the decision on extension of the validity period of the Ukrainian patent for invention. Thus, in the opinion of the plaintiff, the extension of the period of patent validity for an invention is possible only if the object is a product which requires the permission of the competent authority to market placement but not the process (method). In this case, the plaintiff believes that the defendant is not entitled to take decision on the extension of the patent validity period on method of treatment.

The object of the Court case was medical product "MABTERA" registered in the Ministry of Health of Ukraine and patented as invention. In materials of the case, the plaintiff referred to the fact that the Service on intellectual property rights protection was not entitled to extend the validity period of the Ukrainian patent for invention, since the object of the patent is a method of treatment, and not a medicinal product, the use of which requires the permission of the competent authority. At the same time, basing on the materials of the case the formula of the invention consisted two independent points and eight dependent items relating both - the substance that is part of the medicinal product and the method of its application. So, the supplementary protection might be granted to the product as well as to the method as well ${ }^{17}$.

That is why, in our opinion, the regime of prolongation of the patent granted by the national legislation of Ukraine should be extended not only to the invention, the object of which is the medicinal product, but also to the process (method) associated with the manufacture or use of the medicinal product, or for a new use of a known medicinal product or process. In this regard, it is proposed to amend the Art. 6 of the Law of Ukraine "On Protection of Rights to Inventions and Utility Models" and to provide that the period of validity of an invention patent which is the subject of a medicinal product and/or a process (method) related to the manufacture or use of a medicinal product or to a new use of a known medicinal product or process, a means of animal protection, a

\footnotetext{
16 Капіца Ю.М. Право інтелектуальної власності Європейського Союзу та законодавства України. Київ : Видавничий Дім «Слово», 2006. С. 176.

17 Постанова Київського апеляційного господарського суду від 10 лютого 2015 р. у справі № 910/21281/14. URL: http://www.reyestr.court.gov.ua/Review/42665470.
} 
plant protection product, etc., the use of which requires the permission of the relevant competent authority, may be extended at the request of the holder of this patent for a period equal to the period between the filing date and the date of the receipt of such a permit, but not more than 5 years.

\section{Data exclusivity protection under the legislation of Ukraine and the European Union}

In accordance with Part 1 of Article 507 of the Civil Code of Ukraine, bodies of state power are obliged to protect information which contains the commercial secret and the creation of which required considerable efforts from unfair commercial use and received in order to obtain a industrial permit to carry out activities related with pharmaceutical and chemical products which contain new chemical agent; this information is protected by public authorities from disclosure, unless disclosure is necessary to ensure the protection of the population health. Regarding mentioned we can assume that obtaining of the certificate on state registration of the medical product on the market is precisely could be determined as carrying out of the commercial activity in pharmathetical sphere and therefore the registration information on medical products, which contains commercial secrets, is protecting by state authorities. There for the next point which should be clarified is the correlation between trade secrets and registration information on the medical products.

According to A.G. Diduk, one of the particularities of the commercial secretis secrecy mode, which should be understood as complex access to information, the lack of free access to the information due to requirement on preservation from public disclosure by people who received access to it on the legal grounds. The main particularity of the mentioned commercial secret is commercial value of the information meaning that commercial value creates competitive benefits to person who owns such information due to availability of the access to such information and creates bigger possibilities for getting profit from the products manufactured based on information which is the object of the commercial secret ${ }^{18}$.

In addition T.V. Ivchenko mentions that commercial value of the information reflects the ability to bring financial benefits to person who legally controls such information and serves as the source of the profit from business activities ${ }^{19}$. Based on analysis given above, we can assume that both notions: commercial secrets and registration information on medicines have common features as well as differences, or rather specifics that are resided to registration information.

\footnotetext{
18 Дідук А.Г. Правовий режим конфіденційної інформації: цивільно-правовий аспект : дис. ... канд. наук : 12.00 .03 ; Харківський нац. універ. внутр. справ. Харків, 2009. С. 83.

${ }^{19}$ Івченко Т.В. Цивільно-правове регулювання комерційної таємниці як об'єкта права інтелектуальної власності в Україні : дис. ... канд. юрид. наук : 12.00 .03 / НАН України, Ін-т держави і права ім. В.М. Корецького. Київ, 2009. С. 13-15.
} 
Registration information on the medicines should be protected by the State who has the competence to take all measures aimed ensuring its preservation from unlawful disclosure and transferring to physical person and/or legal entity (clause 8 of the Art. 9 of the Law of Ukraine "On Medicines") ${ }^{20}$. Regarding mentioned, it should be noted that, for example, Yu.V. Nosik believes that the right to commercial secret belongs only to the person who identified the information as a commercial secret; due to such identification the person takes all needed actions to preserve information from disclosure creating commercial value of such information ${ }^{21}$.

However specially responsibles state authority does not define the status of the registration information, rather it has legal obligation to take all necessary measures to protect it from unlawful disclosure. Within this context we find it usefull to cite the reference to the Section X of the Procedure for conducting an examination of registration materials on medicinal products submitted for state registration (re-registration), as well as examination of materials on amendments to registration materials during the validity of the registration certificate, approved by the order of the Ministry of Health Protection on 26 August 2005 № $426^{22}$. Mentioned document determines State Expert Center of the Ministry of Health of Ukraine as the state authority which takes actions to protect registration information from unlawful disclosure, collection and usage of such information submitted for registration of the medical drug. However, the feature of the registration information in comparing with commertial secter is that the fact of the registration information protection appers without acquiring the property rights themselves by the State Expert Center of the Ministry of Health. At the same time, it does not mean that physical person or legal entity who submitted the application to the state registration of the medical product is deprived of the opportunity to take all neseccary measures from its disclosure, if such actions are needed to ensure commercial secrecy of the information.

Another point, which should be investigated additionally, is the scope of the registration information that should be protected from unlawful disclosure. The complete list of documents and data needed to be submitted for the state registration of a medicinal product is contained in the Appendices to the Procedure for Examination of Registration Materials for Medicinal Products and includes, among other things, general information about the medicinal product,

\footnotetext{
${ }^{20}$ Дзера О.В. Науково-практичний коментар Цивільного кодексу України. Київ : Юрінком Інтер, 2006. T. I. C. 823.

${ }^{21}$ Носік Ю.В. Права на комерційну таємницю в Україні (цивільно-правовий аспект) : дис. ... канд. юрид. наук : 12.00.03 ; Київ. націон. ун-т ім. Тараса Шевченка. Київ, 2006. С. 123-124.

${ }^{22}$ Порядок проведення експертизи реєстраційних матеріалів на лікарські засоби, що подаються на державну реєстрацію (перереєстрацію), а також експертизи матеріалів про внесення змін до реєстраційних матеріалів протягом дії реєстраційного посвідчення : затв. наказом Міністерства охорони здоров’я України від 26 серпня 2005 р. № 426. URL: http://zakon5.rada.gov.ua/laws/show/z1069-05.
} 
its composition, such as: active substances, excipients, results of analyzes which prove the efficiency and safety of such a medicinal product, etc.

According to Clause 1 of Art. 507 of the Civil Code of Ukraine the precondition for obtaining of the state protection against unfair commercial use of the information is availability of the new chemical substance in composition of the medical product. The requirement to submit the new chemical substance during the process of the medical product registration is contained in Clause 1 of Art. 39 of the TRIPS Agreement, which, according to V. Potekhina, is based on the domination of private interests over public ${ }^{23}$, whith following wording: "Parties of the Agreement are obliged to protect test data or other data creation of which requires considerable efforts and submission of which is the precondition for obtaining of the permission to place on the market pharmaceutical products and agriculture protection products which contain new chemical substances from unfair commercial use, except the cases where it's necessary to protect public health".

Regarding mention the other point, which requires additional research, appears: what are requirements to new chemical substances and are they equal to requirements to new substances, which are the object of the inventions protected by patents.

K. Correa stresses that the TRIPS Agreement does not require that the criteria for determining a new chemical substanceshould meet the criteria defined by the patent law, while there is no restrictions for member states to apply to requirements of the patent law for new chemical substances ${ }^{24}$. Within this context we propose to address to the court practices.

In accordance with the decision of the Commercial Court of Kyiv region in the case dated on April 26, 2010 № 19/139-09 the company "H. Lundbek A/S" is the producer and owner of the intellectual property rights to the original medical product and the holder of the registration certificate for the original medicinal product "Abix" on the basis of the active substance memantine hydrochloride (1-amino-3,5-dimethyladamantane hydrochloride) registered by the Ministry of Health of Ukraine.

In Ukraine, the active ingredient of the drug Abix used for the treatment of dementia and memantine hydrochloride component is the object of patent protection, namely, the company "X. Lundbek A/S" is the owner of exclusive licenses for the use of the Merz Pharma $\mathrm{GmbH}$. In addition to the exclusive patent rights for memantine productsduring 5 years (regardless of the term of any patent validity, which is related to the medicinal product) starting with the date of the first registration, during validity of so-called data exclusivity regime, it's prohibited to

\footnotetext{
${ }^{23}$ Потєхіна В.О. Інтелектуальна власність : навчальний посібник / за ред. І.І. Дахно. Київ : ЦУЛ, 2008. C. 56.

${ }^{24}$ Carlos Correa Trade related aspects of intellectual property rights a commentary on the TRIPS Agreement. New York : OXFORD University Press. 2007. P. 378.
} 
disclose or to use the information submitted for registration of the other medical product which containts the same substance by other physical person or legal entity, except cases when such subjects legally obtained such right.

Therefore, since the original drug has been registered in Ukraine by the Ministry of Health of Ukraine, the mode of data exclusivity is extended for five years to memantine products in Ukraine. In addition, the materials of the registration data, in particular the clinical trials, for memantine hydrochloride can be used exclusively for scientific purposes in the interests of public health protection. However, while they remain the subject of intellectual property rights of the company which carried out its initial research, the registration data could not be used until the exclusivity period expiration ${ }^{25}$.

Thus, it should be noted that the legislation does not establish requirements for the conformity of a new chemical substancesto the same criteria established for chemical substances which are objects of the invention.

At the same time, it should be noted that in case if the chemical substance is protected under patent law, it's easier to prove the unlawfull use of the registration information during production of the generic medical product before the expiration of the five-year period after the state registration of the original medical product.

It should be pointed out that the legislation and practice of foreign countries have established a special regime for the protection of information on medical products, which has the appropriate name and criteria. So, in the European Union, this mode was named "data exclusivity". The translation of this concept is given in the dictionaries of foreign words and can be defined as follows: "exclusivity" - exclusivity, singularity of its kind, and "data" - data, the information that eventually forms a mode called "data exclusivity" 26 .

According to A.V. Mindrul, in a number ofthe most developed member-States of WTO, the obstruction of "unfair commercial use" by the state authorities is used to introduce the regime"data exclusivity" which means the prohibition to refer to data of tests of an original medicinal product during a certain period for the purpose of such medicinal productscopies registration ${ }^{27}$. The researcher believes that the concept of "data exclusivity" should be understood as a mode of preclinical studies, trials and clinical trials of a medical product data protection during which the application for registration of the following

\footnotetext{
25 Рішення Господарського суду Київської області від 26 квітня 2010 р. у справі № 19/139-09. URL: http://www.reyestr.court.gov.ua/ Review/10026637.

${ }_{26}^{26}$ Англо-русский словарь : 53000 слов / авт. Мюллер В.К. Москва : Рус. яз., 1981. С. 190, 263.

27 Міндрул А.В. Співвідношення патентної охорони і охорони даних фармацевтичних досліджень в контексті 173 реалізації вимог Угоди про торговельні аспекти прав інтелектуальної власності у законодавстві України. Теоретичні і практичні аспекти економіки та інтелектуальної власності. 2010. URL: http://eir.pstu.edu/bitstream/handle/123456789/727/13.pdf? sequence=1.
} 
medicinal product can not refer to the specified data prepared for the original medicinal product ${ }^{28}$.

Another researcher M. Krekor notes that "data exclusivity" is a defined period of time during which the authorities are prohibited to confirm the effectiveness of the generic version submitted for state registration produced with use of the clinical and preclinical studies of an already registered original medicinal product $^{29}$.

On the basis of the mentioned above it should be noted that the "data exclusivity" is understood as the specifically established regime according to which it's prohibited to disclose the information related to conducting of preclinical examinations, trials and examinations of a medicinal product submitted for state registration.

At the same time, K. Korrea observes that the protection of such information does not create exclusive rights, but only determines the period during which the information on the examination and researches of innovative medicines could not be disclosed ${ }^{30}$. But we are not able to agree with such notion basing on the European Union Court practice.

In accordance with Clause (i) Part 3 of Art. 6 of Directive 2001/83 of the European Parliament and of the Council on 6 November 2001 on the establishment of a Community Code on medicinal products for human use for the registration of a medicinal products, the applicant must provide toxicological, pharmacological, physico-chemical, biological and microbiological data in a package of documents as well as data on clinical trials. At the same time, mentioned information and data documents should not be submitted if a medicial product contains the same quantitative and qualitative composition of the active substances, the same pharmacological form and is equal to the medical product which is already registered at the market (that is, the original medicinal product) ${ }^{31}$.

Providing an interpretation of this provision of the Directive, the the European Court of Justice in case № C-368/96 32 noted that this provision should be understood as conferring of the exclusive right to use of the results of pharmacological and toxicological examinations and clinical studies contained in

\footnotetext{
${ }^{28}$ Міндрул А.В. Деякі аспекти реалізації Угоди TRIPS щодо охорони нерозголошуваної інформації в законодавстві України в контексті забезпечення доступу до лікарських засобів. Теорія $i$ практика інтелектуальної власності. 2010. № 1 (51). С. 58.

${ }^{29}$ Magdalena Krekora. Contract Manufacturing of Medicines. Netherlands : Kluwer Law International. 2008. 445 p. URL: https://books.google.com.ua/books/about/Contract_Manufacturing_of_Medicines.html?id= xOA7ifLDbVcC\&redir_esc=y.

${ }^{30}$ Carlos Correa Trade related aspects of intellectual property rights a commentary on the TRIPS Agreement. New York : OXFORD University Press. 2007. P. 374.

${ }^{31}$ Community code relating to medical products for human use : Directive on 26 November 2001 № 2001/83. URL: http://ec.europa.eu/health/files/ eudralex/vol1/dir_2001_83_consol_2012/dir_2001_83_cons_2012_en.pdf.

32 Summary of Court Judgment on 10 October 1996 № C-368/96. URL: http://curia.europa.eu/juris/showPdf.jsf;jsessionid=9ea7d2dc30dbe7249ce801c648dbaf4cfd341a24b280.e34Kaxi Lc3qMb40Rch0SaxuKb3n0?text=\&docid $=101225 \&$ pageIndex $=0 \&$ doclang $=E N \&$ mode $=$ req $\&$ dir $=\& o c c=$ first $\& p$ $\operatorname{art}=1 \& \mathrm{cid}=27114$.
} 
the application for submission toregistration of the medicinal producton by its holder.

Taking into account the above mentioned, it should be concluded that the subjects who have at their disposal and filed information about the original medical product have the exclusive rights to permit the use of data on research and examination of medicines. Based on the above-mentioned provisions and circumstances of the court case, we can state certain similar features in the regulation on the protection of information under the regime of commercial secretsand data exclusivity regime. Thus, the regime for the protection of information on the investigation of medicinal products under the regime of commercial secrets confers the owner of such information the exclusive right to authorize the use of the relevant information, the exclusive right to prevent the unlawful disclosure, collection or use of commercial secrets. While under the "data exclusivity" regime, the person who holds the relevant information is only entitled to the exclusive right to use such information.

The approach to setting the deadline for the protection of information related to clinical and preclinical studies and medical examinations, defined by Ukrainian legislation. Thus, according to Clauses 9 and 10 of Art. 9 of the Law of Ukraine "On Medicines" if the medical product is registered for the first time in Ukraine on the basis of the registration information, the state registration of another medical product which contains the same active substance as original medicinal product, is possible not earlier than in five years starting with the date of the first registration of original medical product in Ukraine, unless otherwise is provided by law. This requirement does not apply to cases where the applicant has the right to refer and/or use the registration information on original medicinal product or has submitted his own complete registration information that meets the requirements for the registration of original medicinal product in accordance with the law.Mentioned in Clause 9 of Art. 9 of the Law of Ukraine "On Medicines", term might be extended to six years, if within the first three years after the state registration of the original medical product,more indications which are considered to be particular advantage over existing ones are researched and submitted to specially authorized state authority.

In our opinion the main purpose of such legislative provisions is to resolve the problem of the determination: to what medical products the mode of the "data exclusivity" should be applied and what are the terms starting with which the data of efficiency and safety of the medicines should be used for development and carrying out the expertise as well as when the registered information might be used for public health protection. Mentioned might be confermed by common law.

From the systematic analysis of the rules of law, the Supreme Administrative Court of Ukraine in its Resolution № K-17976/10 concludes that the decision on the state registration (re-registration) of a medicinal product is carried out by the Ministry of Health on the basis of the results of registration materials examination. 
The registration materials which accompany the application must contain information and documents of pre-clinical study and clinical trials of the medicinal product. The applicant is not required to provide results of toxicological and pharmacological tests or clinical trial results if the medical product is essentially similar to a generic medical product that is already registered in Ukraine and the holder of the already registered medicine product agrees that data on pharmacological, toxicological and/or clinical tests contained in the registration dossier could be used for the registration of the generic medicine ${ }^{33}$.

Taking into account the above mentioned, it is possible to state that according to Clauses 9 and 10 of Art. 9 of the Law of Ukraine "On Medicines", the schemefor the term of information on medicinal products protection should look like this: $6=1+(3+2)$, where 5 years is the basic protection and can be extended to 6 years if, during the first three years, the state authority received confirmation that new one or more indications are considered more efficient as exicting component of the medical product.

According to the legislation of the European Union, namely, in accordance with clause (i) of Part 3 of Art. 6 Directive 2001/83 of the European Parliament and of the Council on 6 November 2001 on the establishment of the Community Code on medicinal products for human use, during the registration of a medicinal product the applicant must provide toxicological, pharmacological, physico-chemical, biological and microbiological data in a package of documents on research and clinical trials. At the same time, according to Article 10 of the abovementioned Directive data on such studies may not be provided if so-called generic medical product is registered based on substance with the same quantitative and qualitative composition of the active ingredients, the same pharmacological form and equivalence to a medicinal product which is already registered for market placement (the original medicinal product).

These provisions of the Ukrainian legislation are essentially close to the requirements of the European Union in terms of the absence of the need for submission of data on the research of medicinal products for the generic medical product state registration.

However, according to Clause (a) of Part 1 of the Directive № 2001/83, the state registration of a medicinal product which, in its quantitative and qualitative composition, is identical with a medicinal product authorized for the state registration might be registered and placed to the market circulation not earlier than in 6 years starting with the date of the original medicinal product state registration. The specified period may be extended to 10 years in the case registered medical product was created with the use of high technologies. The formula for protecting the medicinal product under the regime of "data exclusivity" in the European Union is the following: 6 years of basic protection,

\footnotetext{
${ }^{33}$ Ухвала Вищого адміністративного суду України від 02 серпня 2011 р. у справі № K-17976/10. URL: http://www.reyestr.court.gov.ua/ Review/18207934.
} 
which can be extended to 10 years. In this regard, the practice of the Court of Justice will be interesting for consideration.

According to the case law C 36/03 the Prozac's drug in capsules with the active ingredient fluxetin (hereinafter referred to as the drug "A") was registered in 1988. In 1992, a medicinal product with a dosage form in the form of a liquid Prozac (herein after referred to as "B") was registered in Denmark. At first, the applicant of the medicinal product "B" wanted to register it as generic copy of the medicinal product " $\mathrm{A}$ ", but he was denied with registration, since the forms of medicines "A" and "B" were different. In view of this, medicine "B" was registered as the original one.

In 1999 applicant decided to register Liquid Prozac as generic from Medicinal Product "B" registered in 1992. The Authorized Agency refused to register it according with the procedure for registration of medicines as a generic product, based on the fact that perion for information on the medicinal product "B"protection has not yet expired (it was 8 years). Later the applicant submitted the dossier for the registration of the generic version on medical product " $A$ " as term of the protection has already passed, but in this case the ground for the refuse was indication on different pharmaceutical forms of the registered products, namely these are capsules and liquid forms.

Ultimately, applicant has applied to the EU Court for an explanation of the issue raised above. The court ruled that the drug Prozac in the form of a liquid can be registered as generic of medicinal product " $\mathrm{B}$ " only if its pharmaceutical form differs from the form of medicinal product " $A$ " and only in 10 years when product " $A$ " was registered ${ }^{34}$.

Thus, a generic medicinal product can be registered only if it corresponds to the original medicinal product for all its characteristics, including the pharmaceutical form. And the most important particularity is that such registration can take place only after 10 years starting with the date of the original medical product registration.

At the same time, in 2004 the Community Code was amended. Thus, according to Article 8 of the Directive of the European Parliament and of the Council on March 31, 2004 № 2004/27, the new approach to the formula for the protection of information on medical products waspresented.

Thus, according to Directive 2004/27, the applicant may not submit the results of preclinical and clinical studies of medicinal products if there is a reference to a medicinal product registered in a European Union country for at least 8 years at the time of filing an application for the state registration of a generic medicinal product. At the same time, state registration and, accordingly, the circulation of the generic version of the innovative medicinal product can

\footnotetext{
34 Judgment of the Court on 09 December 2004 № C 36/03. URL: http://curia.europa.eu/juris/document/ document.jsf;jsessionid=9ea7d0f130d5037f256d123e485ea4f283df20bb879f.e34KaxiLc3eQc40LaxqMbN4Pah0 $\operatorname{Re} 0$ ?text=\&docid=49743\&pageIndex $=0 \&$ doclang $=E N \&$ mode $=1$ st $\&$ dir $=\&$ occ $=$ first $\&$ part $=1 \& \operatorname{cid}=10231$.
} 
take place only after the expiration of 10 years of state registration of the original medicinal product. In this case, the ten-year period of information protection may be extended to 11 years if in the course of the first 8 years the applicant of the original medicinal product has been applied for state registration of new therapeutic prescriptions of the medicinal product, which are more innovative than those which are already registered.

That is, the formula for calculating the term of data exclusivity protection will look like this: $11=1+(8+2)$, where the total maximum term for the protection of information on medical drug development will be 11 years, 10 years of which is the main term. But, if we look at the above indicated scheme, it can be noted that a significant increase in the timing of the protection of information about an innovative medical drug can result in a delay of the release of generic versions on the market and, therefore, given the importance of protecting public health in the European Union, a transitional period for the entry into force of the relevant legislative provisions has been identified.

Thus, by October 2013, Member States of the European Union were allowed to use the information protection formula in their legislation for 6 years, extended to 10 years. For example, according to the legislation of France, Belgium, Luxembourg, Italy, Sweden, Germany, Netherlands, the term of protection of data exclusivity was almost immediately established with the formula of 10 years. This approach was, among other things, due to the high level of medical products consumption. Thus, according to the EuropeanAssociation of Generic Drugs in France, only 22\% of the total pharmacological market is dedicated to generic drugs, in Ireland the quantity is about $7 \%$, and in Greece is $3-4 \%^{35}$.

\section{CONCLUSIONS}

In view of the all above mentioned it's possible to propose to amend the Art. 6 of the Law of Ukraine "On Protection of Rights to Inventions and Utility Models" and to provide that the period of validity of an invention patent which is the subject of a medicinal product and / or a process (method) related to the manufacture or use of a medicinal product or to a new use of a known medicinal product or process, a means of animal protection, a plant protection product, etc., the use of which requires the permission of the relevant competent authority, may be extended at the request of the holder of this patent for a period equal to the period between the filing date and the date of the receipt of such a permit, but not more than 5 years.

2. The features of registration information for medicinal products are the following:

\footnotetext{
${ }^{35}$ Guide to EU Pharmaceutical Regulatory Law. The Nitherlands : Kluwer Law, International BV, 2011. 682 p. URL: http://www.egagenerics.com/gen-geneurope.htm.
} 
1) access to such information is restricted by the entity which created it, as well as by the state authorities who became aware about the information due to submission of the application for state registration of medicinal products;

2) the registration information has a commercial value;

3 ) the creation of information submitted for the state registration of a medicinal product creates the proprietary rights of its owner, similar to the rights that may be exercised in respect of commercial secrets;

4) information on new chemical substances which are in the composition of the medical product, should be protected by the State against unfair commercial use even if such substances don't meet the requirement of the substance as the subject of the invention.

3. Despite the fact that the legislation does not establish requirements for the compliance of a new chemical compound with the criteria for inventions subject to chemical substances, it should be noted that it follows from the case law that in the case of the patent protection of the relevant chemical, it is easier to prove in court the fact of a violation of the use of the substance for the manufacture of a medicinal product until the end of the five-year period.

4. The mode of data exclusivity is a special regime according to which the information contained in the application for state registration of a medicinal product and its annexes (registration information) is protected by a specially authorized state authority from disclosure and unfair commercial use within the period established by the current legislation.

5. The protection of exclusive data is the established period of time during which information as a condition for the state registration of an original medicinal product is protected by a specially authorized state body that implements state health policy and is calculated according to the formula.

\section{SUMMARY}

The main purpose of this research is do describe particularities of the supplementary patenting system as well as data exclusivity protection in Ukraine and the European Union. Actuality of the described subject seems in the context of ensurance of the public health protection and in the ensurence of the intellectual property rights. The supplementary certification is under research as on of the tools on continuation of the patentee exclusive rights duration. Also particularities of the regulation in Ukraine and European Union are described. As result, proposals on legislation amendments are formed. Another part of the research is dedicated to the point on data exclusivity regulation, it's particularities according to the legislation of Ukraine and the European Union as well. As result the definition of the data exclusivity is proposed as well as analysis on compering of the commercial secret and data exclusivity. 


\section{REFERENCES}

1. Кириченко I.А. Деякі аспекти патентного захисту лікарських засобів. Інтелектуальна власність. 2001. № 9-10. С. 17-24.

2. Угода про торговельні аспекти прав інтелектуальної власності від 15 квітня 1994 p. URL: http://zakon4.rada.gov.ua/laws/show/981_018.

3. Підопригора О.А. Нове законодавство про винахідництво i раціоналізацію : методична розробка ; КДУ ім. Т.Г. Шевченка. Київ, 1975. $98 \mathrm{c}$.

4. Вишневецкий Л.М., Иванов Б.И., Левин Л.Г. Формула приоритета: возникновение и развитие авторского и патентного права. Ленинград : Наука. Ленигр. отд-ние, 1990. 208 с.

5. Свядосц Ю.И. Основные положения патентного права Франции / под общ. ред. М.М. Богуславского ; Гос. ком. по делам изобретений и открытий СССР. Центр. науч.-исслед. ин-т патентной информации и техн.экон. исследований. Москва, 1965. 80 с.

6. Гарилов Э.П. Основные положення патентного права США / под общ. ред. М.М. Богуславского. Москва : ЦНИИПИ, 1966. 72 с.

7. Про введення в дію Закону України «Про охорону прав на винаходи і корисні моделі» : Постанова Верховної Ради України від 23 грудня 1993 р. № 3769-XII. URL: http://zakon2.rada.gov.ua/laws/show/3769-12.

8. Красовська А., Глухівський Л. Деклараційний патент на винахід : завершення життєвого циклу і підсумки. Інтелектуальна власність. 2004. № 3. С. 34-39.

9. Глухівський Л. Деклараційний патент : за і проти. Інтелектуальна власність. 2001. № 7. С. 8-12.

10. Інструкція про порядок продовження строку дії патенту на винахід, об'єктом якого є засіб, використання якого потребує дозволу компетентного органу : затв. наказом Міністерства освіти і науки України від 13 травня 2002 р. № 298. URL: http://zakon3.rada.gov.ua/laws/show/ z0453-02.

11. Supplementary protection certificate for medicinal products : Regulation of the European Parliament and of the Council on 6 May 2009 № 469/2009. Official Journal. 2009. P. 1-10. URL: http://eurlex.europa.eu/ Notice.do?val $=496552:$ cs\&lang=en\&list $=496852: \mathrm{cs}, 496552: \mathrm{cs}, \&$ pos $=2 \&$ page $=1 \&$ nbl $=2 \&$ pgs $=10 \&$ hwords $=\&$ checktexte $=$ checkbox $\& v i s u=\#$ texte .

12. Judgment of the Court on 24 November 2011 № C-322/10. URL: http://eur-lex.europa.eu/legalcontent/EN/TXT/?uri= OJ\%3AC\%3A2012\%3A025\% 3AFULL.

13. Judgment of the Court on 24 November 2011 № C-422/10. URL: http://curia.europa.eu/juris/document/document.jsf?docid=115204\&doclang=en. 
14. Order of the Court (Fourth Chamber) of 25 November 2011 № C518/10. URL: http://eur-lex.europa.eu/legalcontent/EN/TXT/?qid= 1480780405738\&uri= CELEX:62010CB0518.

15. Order of the Court on 9 February 2012 № Case C-442/11. URL: http://curia.europa.eu/juris/document/document.jsf?text=\&docid=120021\&pageI ndex $=0 \&$ doclang $=E N \&$ mode $=1$ st $\&$ dir $=\& o c c=$ first $\&$ part $=1 \& c i d=33888$.

16. Капіца Ю.М. Право інтелектуальної власності Європейського Союзу та законодавства України. Київ : Видавничий Дім «Слово», 2006. $1104 \mathrm{c}$.

17. Постанова Київського апеляційного господарського суду від 10 лютого 2015 p. у справі № 910/21281/14. URL: http://www.reyestr.court.gov.ua/Review/42665470.

18. Дідук А.Г. Правовий режим конфіденційної інформації: цивільноправовий аспект : дис. ... канд. наук : 12.00 .03 ; Харківський нац. універ. внутр. справ. Харків, 2009. 199 с.

19. Івченко Т.В. Цивільно-правове регулювання комерційної таємниці як об'єкта права інтелектуальної власності в Україні : дис. ... канд. юрид. наук : 12.00.03 / НАН України, Ін-т держави і права ім. В.М. Корецького. Київ, 2009. 209 с.

20. Дзера О.В. Науково-практичний коментар Цивільного кодексу України. Київ : Юрінком Інтер, 2006. Т. I. 832 с.

21. Носік Ю.В. Права на комерційну таємницю в Україні (цивільноправовий аспект) : дис. ... канд. юрид. наук : 12.00 .03 ; Київ. націон. ун-т ім. Тараса Шевченка. Київ, 2006. 221 с

22. Порядок проведення експертизи реєстраційних матеріалів на лікарські засоби, що подаються на державну реєстрацію (перереєстрацію), а також експертизи матеріалів про внесення змін до реєстраційних матеріалів протягом дії реєстраційного посвідчення : затв. наказом Міністерства охорони здоров'я України від 26 серпня 2005 р. № 426. URL: http://zakon5.rada.gov.ua/laws/show/z1069-05.

23. Потєхіна В.О. Інтелектуальна власність : навчальний посібник / за ред. І.І. Дахно. Київ : ЦУЛ, 2008. 413 с.

24. Carlos Correa Trade related aspects of intellectual property rights a commentary on the TRIPS Agreement. New York : OXFORD University Press. 2007. $573 \mathrm{p}$.

25. Рішення Господарського суду Київської області від 26 квітня 2010 p. у справі № 19/139-09. URL: http://www.reyestr.court.gov.ua/ Review/10026637

26. Англо-русский словарь : 53000 слов / авт. Мюллер В.К. Москва : Рус. яз., 1981. 888 с.

27. Міндрул А.В. Співвідношення патентної охорони і охорони даних фармацевтичних досліджень в контексті 173 реалізації вимог Угоди про 
торговельні аспекти прав інтелектуальної власності у законодавстві України. Теоретичні і практичні аспекти економіки та інтелектуальної власності. 2010. URL: http://eir.pstu.edu/bitstream/handle/123456789/ 727/13.pdf? sequence $=1$.

28. Міндрул А.В. Деякі аспекти реалізації Угоди TRIPS щодо охорони нерозголошуваної інформації в законодавстві України в контексті забезпечення доступу до лікарських засобів. Теорія $i$ практика інтелектуальної власності. 2010. № 1 (51). С. 51-58.

29. Magdalena Krekora. Contract Manufacturing of Medicines. Netherlands: Kluwer Law International. 2008. 445 p. URL: https://books.google.com.ua/books/about/Contract_Manufacturing_of_Medicine s.html?id=xOA7ifLDbVcC\&redir_esc=y.

30. Community code relating to medical products for human use : Directive on 26 November 2001 № 2001/83. URL: http://ec.europa.eu/health/files/ eudralex/vol1/dir_2001_83_consol_2012/dir_2001_83_cons_2012_en.pdf.

31. Summary of Court Judgment on 10 October 1996 № C-368/96. URL: http://curia.europa.eu/juris/showPdf.jsf;jsessionid=9ea7d2dc30dbe7249ce801c6 48dbaf4cfd341a24b280.e34KaxiLc3qMb40Rch0SaxuKb3n0?text=\&docid=101 $225 \&$ pageIndex $=0 \&$ doclang $=E N \&$ mode $=$ req $\&$ dir $=\& o c c=$ first $\&$ part $=1 \&$ cid $=27$ 114.

32. Ухвала Вищого адміністративного суду України від 02 серпня 2011 p. у справі № K-17976/10. URL: http://www.reyestr.court.gov.ua/ Review/18207934.

33. Judgment of the Court on 09 December 2004 № C 36/03. URL: http://curia.europa.eu/juris/document/document.jsf;jsessionid=9ea7d0f130d5037 f256d123e485ea4f283df20bb879f.e34KaxiLc3eQc40LaxqMbN4Pah0Re0?text= $\&$ docid $=49743 \&$ pageIndex $=0 \&$ doclang $=E N \&$ mode $=1$ st $\&$ dir $=\& o c c=$ first $\&$ part $=$ $1 \&$ cid=10231.

34. Guide to EU Pharmaceutical Regulatory Law. The Nitherlands : Kluwer Law, International BV, 2011. 682 p. URL: http://www.egagenerics.com/gengeneurope.htm.

Information about author: Klochko T. Yu., $\mathrm{PhD}$, Project Manager Nestle Ukraine 72, Verkhnii Val street, Kyiv, Ukraine 